\title{
Content Analysis of Biology Education Research That Used Context-Based Approaches: The Case of Turkey
}

\author{
Burcu Güngör Cabbar (Corresponding author) \\ Necatibey Faculty of Education, Balikesir University \\ 10100, Altieylül, Balikesir, Turkey \\ Tel: 00-90-505-8966236_E-mail: burcu.cabbar@balikesir.edu.tr \\ Hakan Şenel \\ Institüde of Science and Technology, Balikesir University \\ Çağış, Balikesir, Turkey \\ Tel: 00-90-544-7857969Ｅ-mail: hakanindoktoratezi@gmail.com
}

Received: April 26, 2020 Accepted: May 27, 2020 Published: June 2, 2020

doi:10.5296/jei.v6i1.16920 URL: https://doi.org/10.5296/jei.v6i1.16920

\begin{abstract}
Even if the topics are abstract in biology education, they are very suitable for association to daily life. The context-based learning approach is one of the approaches that is student-centered and provides a connection between daily life and scientific knowledge. Research has determined that the context-based learning approach increases the students' learning about the subject, their interest, and motivation by using examples from daily life. In Turkey, the context-based approach first began to be used in chemistry education. This approach was first applied in biology education in 2008. Nineteen theses and articles completed regarding the context-based approach in biology education in Turkey were encountered when researched. All of these studies were done by using experimental methods. It was determined in research conducted with students of different age groups that context-based learning has a positive effect on motivation as well as on academic success. The effect of the method can be investigated by studying different subjects within biology and with different sample groups.
\end{abstract}

Keywords: Context-based learning approach, Biology education, Content analysis 


\section{Introduction}

Teaching in recent years had faced many problems such as the high amount of information to be taught, the lack of relationships between information, and information pollution caused by the ease in terms of acquisition of information and not giving sufficient importance to the information. The effort to overcome these problems has led to the development of various teaching approaches that enable the structuring of knowledge by centering the student. The context-based learning approach is one of them.

Two of the main objectives of science education are to ensure that students are scientifically literate and to develop their high-level cognitive processing skills. Real-life contexts are important for scientific literacy. Learning that is established around a context and established within daily life is more permanent (Avargil, Herscovitz, \& Dori, 2012). Science subjects are very suitable for explanation in relation to real-life problems and for understanding with the help of these contexts. If science education occurs in this way, scientific literacy, scientific processing skills and 21st-century skills will also increase (Gilbert, 2006).

Science, including biology, usually contains abstract and complex topics. It is easy to understand when it is embodied through examples and daily life (Üstün, Yıldırgan, \& Çegiç, 2001). Since the subjects that are not related to daily life are out of context, they are generally studied by students until the exam and then forgotten. Today, theories developed using the experience gained in the teaching process and their practical applications have been integrated into the teaching process. One of these applications is context-based learning with a constructivist learning approach (Acar \& Yaman, 2011).

Education is a multi-stakeholder activity. In the triangle of students, teachers, and knowledge, many auxiliary materials, techniques, and methods are important for the permanence of learning. Strong interaction between students and teachers ensures that the learning environment is healthy. The fact that this point of interaction is connected with life is important for permanence and easy understanding of the information. One of the biggest obstacles in the educational process is the lack of motivation of the student and/or teacher during the learning process. One approach developed to remove this barrier is the context-based approach (Bülbül \& Matthews, 2012).

Contexts are useful when used as a starting point for science teaching, as they improve attitudes towards science even though students might have different levels of interest and motivation towards the context (Tolppanen et al., 2019; King \& Henderson, 2018; Bennet, Lubben, \& Hogarth, 2007). The context-based learning approach enables students to explore scientific concepts through daily life contexts. Thus, it increases students' motivation to learn science, and permanence of knowledge (Barker \& Millar, 1999; Özay-Köse \& Çam-Tosun, 2011, Gilbert, Bulte \& Pilot, 2011; Herranen et al., 2019; Jeffery, Cass, \& Sweeder, 2019).

The context-based teaching model was first introduced as 'Salters Chemistry' (Salters) by a group of researchers working in the field of chemistry education at York University in England in the early 1980s. Afterward, 'Chemistry in Community (ChemCam)' and 'Chemistry in Context (CIC)' in the USA, 'Chemie im Kontext (Chik)' in Germany, 
'Industrial Chemistry (IC)' in Israel and in the Netherlands. He was involved in improving the curricula of many countries with different names such as Chemistry in Practice (ChiP) (Bennett \& Lubben, 2006; Pilot \& Bulte, 2006). In Turkey, under the leadership of Sözbilir in 2007 , it began to be used in chemical education. It was observed that studies about this subject in biology education have been carried out since 2008 .

Context-based teaching has three main elements. These are context, basic knowledge, and method. In teaching, context helps to examine the situation of the subject and to present it from different aspects and relationships. Thus, the subject will not be abstract for students and the relations between daily life and the subject will emerge. The aim is not just to reveal different aspects of the subject. It is also important to determine the basic field knowledge, that is, basic concept information, principles, and generalization frameworks. When basic information is presented in different situations, examples, and relationships with the help of contexts, students are assisted in learning from a broader and connected context. Also, designing a teaching environment in this way is seen as a stimulating factor for students to think about new questions, problems, and phenomena, to work on them, and to develop solution strategies. With the context-based learning approach, many types of research were completed to investigate the effect on students of variables such as student success, attitude, interest, motivation, and problem-solving skills (Acar \& Yaman, 2011; Choi \& Johnson, 2005; Çetin, 2014; Heller \& Hollabaugh, 1992; Holman \& Pilling, 2004; Kesner, Hofstein, \& Ben-Zvi, 1997; Kutu \& Sözbilir, 2011).

When the studies are examined, no teaching method is emphasized in context-based learning. The availability of different methods gives flexibility to the approach and enables it to be used with different strategies.

Topics such as genetics, cell structure, microorganisms, and living chemistry in biology education are abstract topics. Some issues, such as anatomical structures and the environment, are concrete. Associating the topics of biology, defined as life science, with daily life will increase the permanence of information. Context-based learning is one of the recommended methods for use in biology education with this aspect. This research aims to examine research that use the context-based learning in biology education.

Research in different branches in the literature also support the context-based research findings in biology education. For example, Demircioğlu (2008) determined that both success and attitude increased positively as a result of the research he conducted on elementary teacher candidates about the states of matter. In his study in 1995, Rioseco taught physics courses in Chile for 3 years using a context-based approach. In his study, which he compared with lessons taught using traditional methods, he found that there was a positive increase in students' achievements.

\subsection{Purpose of the Study}

This study aims to investigate the biology education studies which use a context-based learning approach in Turkey. For this purpose, answers were sought to the following sub-problems: 
(1) What are the objectives of biology education studies involving the use of a context-based learning approach in Turkey?

(2) What are the methods used by the biology studies involving the use of a context-based learning approach in Turkey?

(3) What are the data collection methods in biology education studies using a context-based learning approach in Turkey?

(4) What are the signs and context-based approach to learning in the results of studies about biology education in Turkey?

\subsection{Importance of the Research}

Research shows that since 2008, the context-based approach has been used in biology education in Turkey. This research examined these studies and content analysis revealed the results in tables. With the context-based learning approach, it is predicted that it will support literature studies by presenting the data to the researchers who want to study from now on. It is also thought that it will be a guide for new studies stated in the research recommendations.

\section{Method}

The researchers used the keywords "context-based learning", "life-based learning" to search for the articles and theses that researched context-based learning in biology education in Turkey. The theses in this research were accessed from the database of the "National Thesis Center". For articles, ULAKBİM and Google Scholar databases were used.

Nineteen studies matching the criteria were reached. These studies were analyzed descriptively according to the categories created in the sub-problems. The research is limited to theses and articles open to access as of October 2019. Apart from the theses and scientific articles, book chapters, oral, poster presentations, etc. presented in congresses were not included in the research. Since biology education focuses on context-based approach research, context-based research conducted in different disciplines is also not covered in this research.

\section{Findings}

The findings are presented in four sections in line with the sub-problems of the study. The first part includes the objectives of the studies, the second part includes the research method used in the studies, the third part includes the data collection tools and sampling method, and finally, the fourth part is about the results of the research.

\subsection{Aims of Biology Education Studies Using Context-Based Learning Approach}

Context-based biology studies are grouped in 12 categories according to the purposes in Table 1. 


\section{Macrothink}

Table 1. Aims of biology education studies using a context-based learning approach

\begin{tabular}{|c|c|c|c|}
\hline & Aims & Researches & $f$ \\
\hline 1 & Effect on academic success & $\begin{array}{l}\text { Çam, 2008; Özay Köse \& Çam Tosun, 2011; Özay } \\
\text { Köse \& Çam Tosun, 2013; Akdaş, 2014; Özay Köse \& } \\
\text { Çam Tosun, 2015; İçöz, 2016; Ünal, 2016; Gül, } \\
\text { Gürbüzoğlu Yalmancı \& Yalmancı, 2017; Konu, 2017; } \\
\text { Sarı Ay, 2017; Gül \& Konu, 2018; Hoşbaş, } 2018\end{array}$ & 12 \\
\hline 2 & Effect on attitude & $\begin{array}{l}\text { Çam, 2008; Akdaş, 2014; Özay Köse \& Çam Tosun, } \\
\text { 2015; } \\
\text { Gül, 2016; Konu, 2017; Konu \& Gül, } 2017\end{array}$ & 6 \\
\hline 3 & Effect on motivation & $\begin{array}{l}\text { Gül, 2016; Gül, Gürbüzoğlu Yalmancı \& Yalmanc1, } \\
\text { 2017; Konu, 2017; Konu \& Gül, } 2017\end{array}$ & 4 \\
\hline 4 & Effect on attitude to the environment & Gürsoy Köroğlu, 2011; İçöz, 2016; Ünal, 2016 & 3 \\
\hline 5 & Effect of information on permanence & Akdaş, 2014; Gül, 2016; Sarı Ay, 2017. & 3 \\
\hline 6 & Effect on cognitive processing skills & $\begin{array}{l}\text { Çam, 2008; Özay Köse \&Çam Tosun, 2013; Hoşbaş, } \\
2018\end{array}$ & 3 \\
\hline 7 & $\begin{array}{l}\text { Conducting and developing the course } \\
\text { suitable for the content-based approach }\end{array}$ & Acar \&Yaman, 2011; Özay Köse \& Çam Tosun, 2011 & 2 \\
\hline 8 & Effect on environmental interest & Gürsoy Köroğlu, 2011; Sarı Ay, 2017. & 2 \\
\hline 9 & Effect on interrogative learning skills & $\begin{array}{l}\text { Gül, 2016; Gül, Gürbüzoğlu Yalmancı, \& Yalmanc1, } \\
2017\end{array}$ & 2 \\
\hline 10 & Effect on problem-solving skills & Konu, 2017; Konu \&Gül, 2017 & 2 \\
\hline 11 & $\begin{array}{l}\text { Effect on understanding the nature of } \\
\text { science }\end{array}$ & Duruk, 2017; Hoşbaş, 2018 & 2 \\
\hline 12 & $\begin{array}{l}\text { Effect on conceptual learning and } \\
\text { alternative concepts }\end{array}$ & Karsli \& Saka, 2017 & 1 \\
\hline
\end{tabular}

As seen in Table 1, in 12 of the 19 studies examined the aim was to examine the effect of context-based learning on academic achievement. As seen from the table, some studies targeted more than one goal and examined the effect of contextual learning in 12 categories. In addition to the studies investigating the effect of context-based learning on attitude and motivation towards the course, the effects of learning processes and permanence were also examined. It is observed that a study was also conducted on context-based question writing and the effect of the context-based approach in the measurement and evaluation process. 


\subsection{Method of Context-Based Biology Education Studies in Turkey}

The studies examined were analyzed in terms of the method used and divided into two groups, theoretical and experimental, and are presented in Table 2. Theoretical research involved scanning, selecting, analyzing, and classifying documents and completing logical analysis within the framework of previous research. Experimental research includes research based on practice, experiment, or observation, not just a theory.

Table 2. Method of context-based biology studies

\begin{tabular}{|l|l|l|l|}
\hline & Studies (sorted by date) & Theoretical studies & Experimental Studies \\
\hline $\mathbf{1}$ & Çam, 2008 & & $\checkmark$ \\
\hline $\mathbf{2}$ & Acar \&Yaman, 2011 & & $\checkmark$ \\
\hline $\mathbf{3}$ & Gürsoy Köroğlu, 2011 & & $\checkmark$ \\
\hline $\mathbf{4}$ & Özay Köse \& Çam Tosun, 2011 & & $\checkmark$ \\
\hline $\mathbf{5}$ & Özay Köse \& Çam Tosun, 2013 & & $\checkmark$ \\
\hline $\mathbf{6}$ & Akdaş, 2014 & & $\checkmark$ \\
\hline $\mathbf{7}$ & Özay Köse \& Çam Tosun, 2015 & & $\checkmark$ \\
\hline $\mathbf{8}$ & Gül, 2016 & & $\checkmark$ \\
\hline $\mathbf{9}$ & İçöz, 2016 & & $\checkmark$ \\
\hline $\mathbf{1 0}$ & Ünal, 2016 & & $\checkmark$ \\
\hline $\mathbf{1 1}$ & Duruk, 2017 & & $\checkmark$ \\
\hline $\mathbf{1 2}$ & Gül, Gürbüzoğlu Yalmanc1, \&Yalmanc1, 2017 & & $\checkmark$ \\
\hline $\mathbf{1 3}$ & Karsli \& Saka, 2017 & & $\checkmark$ \\
\hline $\mathbf{1 4}$ & Konu, 2017 & & $\checkmark$ \\
\hline $\mathbf{1 5}$ & Konu \& Gül, 2017 & & $\checkmark$ \\
\hline $\mathbf{1 6}$ & Sar1 Ay, 2017 & & $\checkmark$ \\
\hline $\mathbf{1 7}$ & Yeşilyurt, 2017 & & $\checkmark$ \\
\hline $\mathbf{1 8}$ & Gül \&Konu, 2018 & & $\checkmark$ \\
\hline $\mathbf{1 9}$ & Hoşbaş, 2018 & & $\checkmark$ \\
\hline
\end{tabular}

In Table 2, all 19 studies related to the context-based approach in biology education were experimental studies. When looking at studies in field education, it is possible to say that experimental study is dominant. The designs of the studies were experimental or 
quasi-experimental designs and mixed methods were preferred.

In Table 2 , the $4^{\text {th }}, 5^{\text {th }}$ and $7^{\text {th }}$ studies were by Özay Köse et al. The $8^{\text {th }}, 14^{\text {th }}$ and $15^{\text {th }}$ studies about the subject were by Gül. There are studies performed by the same researchers for different purposes and different groups. Researchers focusing on this subject have completed their research with experimental studies.

\subsection{Data Collection Tools of Biology Education Studies Using a Context-Based Learning Approach}

The data collection methods of 19 studies related to biology education using a context-based learning approach and information about how the sample was chosen are presented in Table 3. 
Table 3. Data collection tools and sampling types of context-based biology education studies

\begin{tabular}{|c|c|c|c|c|c|c|c|c|c|c|c|c|}
\hline \multirow{4}{*}{\multicolumn{2}{|c|}{ Studies (sorted by date) }} & \multicolumn{6}{|c|}{ Data Collection Tools } & \multicolumn{5}{|c|}{ Sample } \\
\hline & & \multirow{4}{*}{ 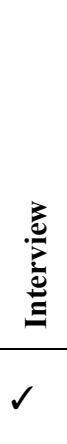 } & \multirow{3}{*}{ 童 } & \multirow{3}{*}{ مُ } & \multicolumn{3}{|c|}{ Paper surveys } & \multirow{3}{*}{$\begin{array}{l}\text { Sample size } \\
\text { and group }\end{array}$} & \multicolumn{4}{|c|}{ Sampling Type } \\
\hline & & & & & & Surve & & & \multirow{2}{*}{ 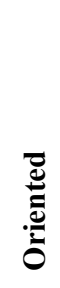 } & \multirow{3}{*}{ 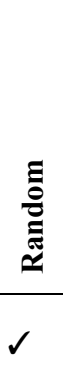 } & \multirow{2}{*}{ 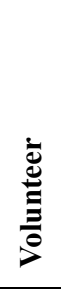 } & \multirow{2}{*}{ 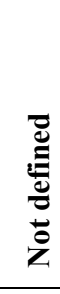 } \\
\hline & & & & & & & & & & & & \\
\hline 1 & Çam, 2008 & & & & $\checkmark$ & $\checkmark$ & $\checkmark$ & $\begin{array}{l}94 \text { (teacher } \\
\text { candidates) }\end{array}$ & & & & \\
\hline 2 & Acar \&Yaman, 2011 & & & & & $\checkmark$ & $\checkmark$ & $\begin{array}{l}191 \text { ( } 9 \text { th class } \\
\text { students) }\end{array}$ & & $\checkmark$ & & \\
\hline 3 & Gürsoy Köroğlu, 2011 & $\checkmark$ & & & $\checkmark$ & $\checkmark$ & & $\begin{array}{l}30 \text { (teacher } \\
\text { candidates) }\end{array}$ & & & & $\checkmark$ \\
\hline 4 & $\begin{array}{l}\text { Özay Köse \& } \\
\text { Çam Tosun, } 2011\end{array}$ & & & & $\checkmark$ & & $\checkmark$ & $\begin{array}{l}37 \text { (teacher } \\
\text { candidates) }\end{array}$ & $\checkmark$ & & & \\
\hline 5 & $\begin{array}{l}\text { Özay Köse \& } \\
\text { Çam Tosun, } 2013\end{array}$ & & & & & $\checkmark$ & $\checkmark$ & $\begin{array}{l}94 \text { (teacher } \\
\text { candidates) }\end{array}$ & & $\checkmark$ & & \\
\hline 6 & Akdaş, 2014 & & & & & $\checkmark$ & $\checkmark$ & $\begin{array}{l}43 \text { ( } 7 \text { th class } \\
\text { students) }\end{array}$ & $\checkmark$ & & & \\
\hline 7 & $\begin{array}{l}\text { Özay Köse \& } \\
\text { Çam Tosun, } 2015\end{array}$ & $\checkmark$ & & & & $\checkmark$ & $\checkmark$ & $\begin{array}{l}94 \text { (teacher } \\
\text { candidates) }\end{array}$ & & $\checkmark$ & & \\
\hline 8 & Gül, 2016 & $\checkmark$ & & & & $\checkmark$ & $\checkmark$ & $\begin{array}{l}52 \text { ( } 11 \text { th class } \\
\text { student) }\end{array}$ & $\checkmark$ & & & \\
\hline 9 & İçöz, 2016 & & & & $\checkmark$ & $\checkmark$ & $\checkmark$ & $\begin{array}{l}113 \text { (10th class } \\
\text { student) }\end{array}$ & $\checkmark$ & & & \\
\hline 10 & Ünal, 2016 & & & & $\checkmark$ & $\checkmark$ & $\checkmark$ & $\begin{array}{l}67 \text { (9th class } \\
\text { students) }\end{array}$ & $\checkmark$ & & & \\
\hline 11 & Duruk, 2017 & & & & & & & $\begin{array}{l}65 \text { (teacher } \\
\text { candidate) }\end{array}$ & & & & \\
\hline 12 & $\begin{array}{l}\text { Gül, Gürbüzoğlu Yalmanc1, } \\
\text { \& Yalmanc1, } 2017\end{array}$ & & & & & $\checkmark$ & $\checkmark$ & $\begin{array}{l}58 \text { ( } 10 \text { th class } \\
\text { student) }\end{array}$ & & & $\checkmark$ & \\
\hline 13 & Karsli \& Saka, 2017 & $\checkmark$ & & & $\checkmark$ & & $\checkmark$ & $\begin{array}{l}40 \text { ( } 5 \text { th class } \\
\text { student })\end{array}$ & & $\checkmark$ & & \\
\hline 14 & Konu, 2017 & $\checkmark$ & & & & $\checkmark$ & $\checkmark$ & $\begin{array}{l}106 \text { ( } 11 \text { th class } \\
\text { student) }\end{array}$ & & $\checkmark$ & & \\
\hline 15 & Konu \& Gül, 2017 & & & & & $\checkmark$ & & $\begin{array}{l}106(11 \text { th class } \\
\text { student })\end{array}$ & & $\checkmark$ & & \\
\hline 16 & Sar1 Ay, 2017 & & & & & & & $\begin{array}{l}60 \text { ( } 5 \text { th class } \\
\text { student) }\end{array}$ & $\checkmark$ & & & \\
\hline 17 & Yeşilyurt, 2017 & & & & & & $\checkmark$ & $\begin{array}{l}21 \text { ( } 5 \text { th class } \\
\text { student })\end{array}$ & & & & $\checkmark$ \\
\hline 18 & Gül \& Konu, 2018 & $\checkmark$ & & & & & $\checkmark$ & $\begin{array}{l}106 \text { ( } 11 \text { th class } \\
\text { student) }\end{array}$ & & $\checkmark$ & & \\
\hline 19 & Hoşbaş, 2018 & & & & & $\checkmark$ & $\checkmark$ & $\begin{array}{l}50 \text { ( } 7 \text { th class } \\
\text { student) }\end{array}$ & & & & $\checkmark$ \\
\hline
\end{tabular}


When Table 3 is examined, no study was found to collect data with the help of a portfolio. The sampling method of 1 research was not mentioned. While only 1 study used a voluntary sampling method, 6 studies were carried out and 8 studies were carried out with a random sampling method. Likert or multiple-choice questionnaire were used in all studies except for one study.

\subsection{Findings and Results of Biology Education Studies Using Context-Based Learning Approach}

Table 4 contains summaries of the findings and results of the studies.

Table 4. Findings and Results of Biology Education Studies Using Context-Based Learning Approach

\begin{tabular}{|c|c|c|}
\hline \multicolumn{2}{|c|}{ Research } & \multirow{2}{*}{$\begin{array}{l}\text { Findings and results } \\
\text { When the context-based learning approach is used, it was found to cause more success } \\
\text { than traditional teaching method. }\end{array}$} \\
\hline 1 & Çam, 2008 & \\
\hline 2 & Acar \&Yaman, 2011 & $\begin{array}{l}\text { The courses designed and applied with the context-based learning approach positively } \\
\text { affected the students' understanding of the subject of "microorganisms". The } \\
\text { context-based learning approach is important in terms of stimulating students' interests } \\
\text { and wishes. It affects success positively as it includes activities aimed at developing } \\
\text { biological ideas. }\end{array}$ \\
\hline 3 & Gürsoy Köroğlu, 2011 & $\begin{array}{l}\text { Conscious consumer behaviors of biology teacher candidates changed with the } \\
\text { "Context-Based Learning Approach Prepared for Biodiversity and Nature } \\
\text { Conservation". Influencing behavior shows that a very high level of cognitive behavior } \\
\text { occurs. Their interest in the environment and their attitudes towards biodiversity and } \\
\text { nature protection increased positively when the pretest-posttest scores are compared. }\end{array}$ \\
\hline 4 & $\begin{array}{l}\text { Özay Köse \& } \\
\text { Çam Tosun, } 2011\end{array}$ & $\begin{array}{l}\text { There was a significant difference in students' academic achievements after applying a } \\
\text { context-based learning approach. Although it was not observed to affect academic } \\
\text { success sufficiently in every subject, this research supports the studies with findings that } \\
\text { it affects academic success positively. }\end{array}$ \\
\hline 5 & $\begin{array}{l}\text { Özay Köse \& } \\
\text { Çam Tosun, } 2013\end{array}$ & $\begin{array}{l}\text { A significant difference was determined in terms of the success and scientific processing } \\
\text { skills of education designed with the context-based learning approach compared to } \\
\text { groups in which traditional education was conducted. Activities designed with the } \\
\text { context-based learning approach increased the success and scientific processing skills } \\
\text { positively. }\end{array}$ \\
\hline 6 & Akdaş, 2014 & $\begin{array}{l}\text { One of the approaches that positively affects students' academic achievements towards } \\
\text { environmental thinking, behavior, and subject are activities based on the context-based } \\
\text { learning model. This research, which was determined to have a positive effect on the } \\
\text { permanence levels of information, is one of many studies that determine the positive } \\
\text { effect of the context-based learning approach on permanence. }\end{array}$ \\
\hline 7 & Özay Köse \& & As a result of the application based on context-based learning, it was shown that there is \\
\hline
\end{tabular}




\begin{tabular}{|c|c|c|}
\hline & Çam Tosun, 2015 & $\begin{array}{l}\text { a significant difference in terms of students' achievements and attitudes compared to the } \\
\text { traditional method. The results of interviews also supported these findings. }\end{array}$ \\
\hline 8 & Gül, 2016 & $\begin{array}{l}\text { The method used did not have a statistically significant effect on students' attitudes, } \\
\text { motivation, and questioning learning skills perceptions. However, it revealed that } \\
\text { learning provides permanence. }\end{array}$ \\
\hline 9 & İçöz, 2016 & $\begin{array}{l}\text { The results showed that context-based education has a positive effect on students' } \\
\text { academic success and attitudes towards the environment compared to traditional } \\
\text { education. The interactions of the method and school type used are statistically } \\
\text { significant on students' attitudes towards the environment; however, it is not statistically } \\
\text { significant on students' success. When comparing school type scores, no statistically } \\
\text { significant difference was found between different school types. }\end{array}$ \\
\hline 10 & Ünal, 2016 & $\begin{array}{l}\text { In the teaching of environmental issues in a biology lesson, case study, and research } \\
\text { inquiry-based science learning methods regarding a context-based approach were } \\
\text { applied for the context-based approach. When the results are analyzed, the methods used } \\
\text { increased academic success about environmental issues and that students developed } \\
\text { attitudes towards environmental problems and increased their attitudes. }\end{array}$ \\
\hline 11 & Duruk, 2017 & $\begin{array}{l}\text { When the findings related to quantitative and qualitative data were analyzed together, the } \\
\text { participants in the experimental group showed more significant development in terms of } \\
\text { quantitative findings and qualitative findings in terms of producing scientific knowledge } \\
\text { in a socio-cultural environment. Therefore, it was concluded that the nature of the } \\
\text { context-based science based on metacognitive strategies was effective in developing an } \\
\text { understanding of this component, but it provided low persistence at rates similar to that } \\
\text { of context-based teaching applied in the control group in terms of permanence. }\end{array}$ \\
\hline 12 & $\begin{array}{l}\text { Gül, Gürbüzoğlu } \\
\text { Yalmancı \& } \\
\text { Yalmanc1, } 2017\end{array}$ & $\begin{array}{l}\text { The relationship between context-based learning and perceptive learning skill perception } \\
\text { was examined. When students' Questioning Learning Skills Perception Scale was } \\
\text { examined, the post-test scores obtained from the scale did not show a statistically } \\
\text { significant difference. Although this is thought-provoking when the average difference } \\
\text { between the scale scores before and after the application is examined, it is understood } \\
\text { that there was an increase in the scores of both groups and this increase is much more in } \\
\text { the experimental group. }\end{array}$ \\
\hline 13 & Karsli \& Saka, 2017 & $\begin{array}{l}\text { The subject of 'Let's Know Foods' was covered in the learning environment designed } \\
\text { according to the REACT strategy from the Context-Based Approach. The data obtained } \\
\text { at the end of the application were found to have a positive effect on students' conceptual } \\
\text { understanding. Also, it was concluded that the learning environment designed according } \\
\text { to the REACT strategy is more effective than the learning environment designed } \\
\text { according to the } 5 \mathrm{E} \text { teaching model in terms of students' conceptual changes. }\end{array}$ \\
\hline 14 & Konu, 2017 & $\begin{array}{l}\text { Success tests of the digestive and circulatory systems were applied in the study. When } \\
\text { the findings of the digestive system test were examined, there was no significant } \\
\text { difference between the experimental and control group posttest success scores. However, } \\
\text { when the findings of the circulatory system success test were examined, a statistically } \\
\text { significant increase was found in favor of the experimental group. This shows that the } \\
\text { method has different effects in different subjects. It was determined that the students' }\end{array}$ \\
\hline
\end{tabular}




\begin{tabular}{|c|c|c|}
\hline & & $\begin{array}{l}\text { attitude, motivation, and problem-solving skills were at a high level before and after the } \\
\text { application and there was no statistically significant difference between the groups. } \\
\text { Semi-structured interviews were held with students. At the end of the interviews, it was } \\
\text { determined that the method has some disadvantages for some subjects. According to the } \\
\text { interviews, the students stated mostly positive opinions about context-based } \\
\text { problem-based learning practices. }\end{array}$ \\
\hline 15 & Konu \& Gül, 2017 & $\begin{array}{l}\text { No statistically significant difference was found between the averages of the pre-test and } \\
\text { post-test scores obtained from the Students' Biology Course Attitude Scale. When the } \\
\text { findings of the students' scores obtained from the Biology Lesson Motivation } \\
\text { Questionnaire were examined, the pretest scores of both groups were "high" before the } \\
\text { application and a higher increase was observed in favor of the experimental group after } \\
\text { the application. It was revealed that there was no statistically significant difference } \\
\text { between the mean scores obtained from the Problem Solving Inventory applied to the } \\
\text { students as pre-test and post-test. }\end{array}$ \\
\hline 16 & Sarı Ay, 2017 & $\begin{array}{l}\text { The students expressed a positive opinion about their learning environment. The results } \\
\text { showed that the method used increased student success and environmental awareness, } \\
\text { and ensured the permanence of information. }\end{array}$ \\
\hline 17 & Yeşilyurt, 2017 & $\begin{array}{l}\text { In the study, applications suitable for the contextual approach for nutrition awareness } \\
\text { were designed for students. Looking at the findings, applications contributed to students' } \\
\text { awareness of nutrition. }\end{array}$ \\
\hline 18 & Gül \& Konu, 2018 & $\begin{array}{l}\text { A successful test was applied after the application. The findings of the Digestive System } \\
\text { Success Test revealed that there was no statistically significant difference between the } \\
\text { groups in terms of the students' post-test scores. When the findings of the Circulatory } \\
\text { System Success Test were examined, there was a statistically significant increase } \\
\text { between the groups in favor of the experimental group. Semi-structured interview data } \\
\text { show that although students mention some disadvantages regarding the method, they } \\
\text { report very positive opinions. }\end{array}$ \\
\hline 19 & Hoşbaş, 2018 & $\begin{array}{l}\text { It was determined that the context-based learning approach significantly increased the } \\
\text { academic success of the students in the experimental group, and when their opinions } \\
\text { about the nature of science were examined, there was a significant difference between } \\
\text { the posttest and retention test. It was determined that there was no effect on the scientific } \\
\text { process skills since the posttest and permanence test scores were close to each other, and } \\
\text { the achievement scores and scientific process skills did not differ according to gender. } \\
\text { When only opinions about the nature of science are analyzed, it is concluded that male } \\
\text { students had higher values than female students. }\end{array}$ \\
\hline
\end{tabular}

Looking at Table 4, 19 studies can be seen. When we look at the authors of these studies, the same researchers are working on this subject alone and with different scientists. They researched the subject in depth with different dimensions and different samples. When the findings of the research are analyzed, the applications made with the context-based learning approach generally affect academic success, attitude, and motivation positively. Konu and 
Gül (2017) stated that the findings of the research included disadvantages about the method and that the same success was not seen in every subject.

In all of the context-based research about environmental issues, some findings positively affect success and attitude. Regarding persistence, some of the research included positive findings and some had no differences.

\section{Discussion}

In line with the findings obtained in the research, the subjects of biology lessons are related to daily life and can easily be designed with methods appropriate to the context-based approach. Studies conducted by Gül (2016), Gül, Gürbüzoğlu Yalmanc1, and Yalmanc1 (2017), Konu (2017), and Konu and Gül (2017) reveal that the context-based approach is a method that can increase students' interest and motivation towards the course.

The increase in interest and motivation naturally increases academic success.

The context-based learning approach enables students to make connections between the situations encountered in their daily lives and the subject. It does not contain contextual events and real-life situations and allows students to learn by building a context with their life experience. Thanks to the activities created based on context-based learning, the information gained in the lessons is more easily remembered. This situation increases the permanence of the information (Akdaş, 2014; Gül, 2016; Sarı Ay, 2017; Williams, 2019). Even if it does not have the same effect in every subject, its positive effect on motivation accelerates the process of obtaining information.

For this reason, it may be suggested to apply these applications to different biology subjects or subjects belonging to other courses.

Additionally, Karslı and Yiğit (2015) investigated the effect of the context-based approach on conceptual understanding in their study and determined that they overcame the misconceptions about alkanes better than traditional methods. In biology education, conducting research to determine the effect of context-based learning on conceptual understanding will contribute to the field.

If the learner can make sense of the knowledge, learning at the conceptual level takes place. This information is transferred to other situations and used for the solution to problems, indicating that the learner has higher-level skills in cognitive processing skills. According to the context-based learning approach, the student can use any environment they are in to achieve conceptual learning. The learning environment should be prepared in line with the interests and abilities of the students. Many different social, cultural, and physical environments in which conceptual learning can occur should be made suitable for learning. Questions and situations that will connect these environments with real-life will increase the permanence of information and motivation about the subject.

Looking at samples of the studies, most were completed with students in formal education. Studies with teachers and preservice teachers are important to determine the effect of the context-based learning approach. 


\section{References}

Acar, B., \& Yaman, M. (2011). Bağlam temelli öğrenmenin öğrencilerin ilgi ve bilgi düzeylerine etkisi. Hacettepe Üniversitesi Ĕ̆itim Fakültesi Dergisi, 40, 1-10. Retrieved from https://dergipark.org.tr/tr/pub/hunefd/issue/7796/102051

Akdaş, E. (2014). Illköğretim yedinci sınıf fen ve teknoloji dersi insan ve çevre ünitesinde yaşam temelli öğrenme modelini kullanmanın akademik başarı, tutum ve kalıcılık üzerine etkisi (Unpublished Master Thesis, Gazi Üniversitesi, Eğitim Bilimleri Enstitüsü, Ankara).

Avargil, S., Herscovitz, O., \& Dori, Y. J. (2012). Teaching thinking skills in context based learning: Teachers' challenges and assessment knowledge. Journal of Science Education and Technology, 21(2), 207-225. https://doi.org/10.1007/s10956-011-9302-7

Barker, V., \& Millar, R. (1999). Students' reasoning about basic chemical reactions: What changes occur during a context-based post-16 chemistry course? International Journal Science Education, 21(6), 645-665. https://doi.org/10.1080/095006999290499

Bennet, J., \& Lubben, F. (2006). Context-based chemistry: The Salters approach. International Journal of Science Education, 28(9), 999-1015. https://doi.org/10.1080/095006 90600702496

Bennett, J., Lubben, F., \& Hogarth, S. (2007). Bringing science to life: A synthesis of the research evidence on the effects of context-based and STS approaches to science teaching. Science Education, 91, 347-370. https://doi.org/10.1002/sce.20186

Bülbül, M. Ş., \& Matthews, K. (2012). Bă̆lam temelli eğitimin olast geleceği (p. 548). X. Ulusal Fen Bilimleri ve Matematik Eğitimi Kongresi, Niğde. Retrieved from http://kongre.nigde.edu.tr/xufbmek/dosyalar/tam_metin/pdf/2487-30_05_2012-22_56_57.pdf

Çam, F. (2008). Biyoloji derslerinde yaşam temelli öğrenme yaklaşımının etkileri (Unpublished Master Thesis, Atatürk Üniversitesi, Fen Bilimleri Enstitüsü, Erzurum).

Demircioğlu, H. (2008). Sını ögretmeni adaylarına yönelik maddenin halleri konusu ile ilgili bağlam temelli materyal geliştirilmesi ve etkililiğinin araştırılması (Unpublished Doctorate Thesis, KTÜ Fen Bilimleri Enstitüsü, Trabzon).

Duruk, Ü. (2017). Üst bilişsel stratejilere dayalı bağlam temelli doğrudan yansitıcı bilimin doğası ögretimi yaklaşımının fen bilimleri öğretmen adaylarının bilimin doğası anlayışlarına ve bu anlayışların kalıcılı̆̆ına etkisi (Unpublished Doctorate Thesis, Adıyaman Üniversitesi, Fen Bilimleri Enstitüsü, Adıyaman).

Gilbert, J. K. (2006). On the nature of "context" in chemical education. International of Science Education, 28(9), 957-976. https://doi.org/10.1080/09500690600702470

Gilbert, J. K., Bulte, A. M., \& Pilot, A. (2011). Concept development and transfer in context-based science education. International Journal of Science Education, 33(6), 817-837. https://doi.org/10.1080/09500693.2010.493185

Gül, Ş. (2016). Yaşam temelli öğretim modeliyle "fotosentez" konusunun öğretimi: REACT 
stratejisine dayalı bir uygulama. Necatibey Eğitim Fakültesi Elektronik Fen ve Matematik Ĕ̈itimi Dergisi (EFMED), 10(2), 21-45. https://doi.org/10.17522/balikesirnef.273962

Gül, Ş., \& Konu, M. (2018). Yaşam temelli probleme dayalı öğretim uygulamalarının öğrenci başarısına etkisi. Yaşadıkça Eğitim, 32(1), 45-68.

Gül, Ş., Gürbüzoğlu Yalmanc1, S., \& Yalmanc1, E. (2017). Boşaltım sistemi konusunun öğretiminde REACT stratejisinin etkisi. Kastamonu Eğitim Dergisi, 25(1), 79-96. https://doi.org/10.24106/kefdergi.415710

Gürsoy Köroğlu, N. (2011). Yaşam temelli öğrenme yaklaşımının, öğretmen adaylarında çevreye yönelik ilgi, tutum ve çevre bilinçli tüketici davranışlarının incelenmesi (Unpublished Doctorate Thesis, Gazi Üniversitesi, Eğitim Bilimleri Enstitüsü, Ankara).

Herranen, J., Kousa, P., Fooladi, E., \& Aksela M. (2019). Inquiry as a context-based practice - A case study of pre-service teachers' beliefs and implementation of inquiry in context-based science teaching, International Journal of Science Education, 41(14), 1977-1998. https://doi.org/10.1080/09500693.2019.1655679

Hoşbaş, A. A. (2018). Fen bilimleri ögrretiminde yaşam temelli öğrenme yaklaşımının ögrenme ürünleri üzerine etkisi (Yayımlanmamış yüksek lisans tezi). Kırıkkale Üniversitesi, Fen Bilimleri Enstitüsü, Kırıkkale.

İçöz, Ö. F. (2016). Bağlam temelli öğretimin 10. sinıf öğrencilerinin fosil yakutlar ve temiz enerji kaynaklarl konusunu anlamalarına ve çevreye yönelik tutumlarına etkisinin araştırılması (Unpublished Doctorate Thesis, Ortadoğu Teknik Üniversitesi, Fen Bilimleri Enstitüsü, Ankara).

Jeffery, K. A., Cass, S. M. F., \& Sweeder, R. D. (2019). Comparison of students' readily accessible knowledge of reaction kinetics in lecture-and context-based courses. Journal of STEM Education: Innovations and Research, 19(5).

Karslı, F., \& Saka, Ü. (2017). 5. sınıf öğrencilerinin 'besinleri tanıyalım' konusundaki kavramsal anlamalarına bağlam temelli yaklaşımın etkisi. İlköğretim Online, 16(3), 900-916. https://doi.org/10.17051/ilkonline.2017.330230

Karslı, F., \& Yiğit, M. (2015). Lise 12. sınıf öğrencilerinin alkanlar konusundaki kavramsal anlamalarına bağlam temelli öğrenme yaklaşımının etkisi. Inönü Üniversitesi Ĕ̆itim Fakültesi Dergisi, 16(1), 43-62. https://doi.org/10.17679/iuefd.16124860

King, D., \& Henderson, S. (2018). Context-based learning in the middle years: Achieving resonance between the real-world field and environmental science concepts. International Journal of Science Education, 40(10), 1221-1238. https://doi.org/10.1080/09500693.2018. 1470352

Konu, M. (2017). Yaşam temelli probleme dayalı öğretim uygulamalarının öğrencilerin biyoloji dersindeki başarılarına, tutumlarına, motivasyonlarına ve problem çözme becerilerine etkisi (Unpublished Doctorate Thesis, Atatürk Üniversitesi, Eğitim Bilimleri Enstitüsü, Erzurum). 


\section{Macrothink}

Konu, M., \& Gül, Ş. (2017). Biyoloji dersinde yaşam temelli probleme dayalı öğretim uygulamalarının tutum, motivasyon ve problem çözme becerilerine etkisi. Hasan Ali Yücel Ĕgitim Fakültesi Dergisi, 14(1), 127-142.

Özay, K. E., \& Çam, T. F. (2011). Yaşam temelli öğrenmenin sinir sistemi konusunda öğrenci başarılarına etkileri. Journal of Turkish Science Education, 8(2), 91-106.

Özay, K. E., \& Çam, T. F. (2013). Biyoloji öğretiminde başarı ve bilimsel süreç becerilerine yaşam temelli öğrenmenin etkileri. Iğdır Üniversitesi Fen Bilimleri Enstitüsü Dergisi, 3(4), 33-41. Retrieved from https://dergipark.org.tr/tr/pub/jist/issue/7936/384723

Özay, K. E., \& Çam, T. F. (2015). Biyolojide yaşam temelli öğrenmenin öğrencilerin başarı ve tutumlarına etkisi. Kastamonu Ĕgitim Dergisi, 23(4), 1425-1436. Retrieved from https://dergipark.org.tr/tr/pub/kefdergi/issue/22597/241373

Pilot, A., \& Bulte, A. M. W. (2006). Why do you "need to know?" context-based education. International Journal Science Education, 28(9), 953-956. https://doi.org/10.1080/09500690 600702462

Rioseco, M. (1995). Context related curriculum planning for science teaching: A proposal to teach science around ozone problem, Science Education International, 6(4), 10-16.

Sarı Ay, Ö. (2017). Yaşam temelli fen ĕgitiminin öğrenci başarısına ve çevre bilinci üzerine etkisi (Unpublished Doctorate Thesis, Hacettepe Üniversitesi, Eğitim Bilimleri Enstitüsü, Ankara).

Sözbilir, M., Sadi, S., Kutu, H., \& Yıldırım, A., (2007). Kimya eğitiminde içeriğe/bağlama dayalı (Context-Based) ögretim yaklaşımı ve dünyadaki uygulamaları. I. Ulusal Kimya Eğitimi Kongresi, s. 108, İstanbul.

Toippanen, S., Jappinen, I., Karkkainen, S., Salonen, A., \& Keinonen, T. (2019). Relevance of life-cycle assessment in context-based science education: A case study in lower secondary school. Sustainability, 11(21), 5877. https://doi.org/10.3390/su11215877

Ünal, Ş. (2016). Biyoloji dersi çevre konularının öğretiminde yaşam temelli yaklaşıma dair örnek olay inceleme ve araştırma sorgulama temelli bilim ögrrenme yöntemlerinin etkisi (Unpublished doctorate thesis, Gazi Üniversitesi, Eğitim Bilimleri Enstitüsü, Ortaöğretim Fen ve Matematik Alanları Eğitimi Anabilim Dalı, Ankara).

Üstün, P., Yıldırgan, N., \& Çegiç, E. (2001). Fen bilgisi eğitiminde model kullanma ile ögretimin başarıya etkisi. yeni bin yılın başında. Fen Bilimleri Eğitimi Sempozyumu, 7-8 Eylül, Maltepe Üniversitesi Eğitim Fakültesi.

Williams, D. P. (2019). 9 Context-and problem-based learning in chemistry in higher education. Teaching Chemistry in Higher Education: A Festschrift in Honour of Professor Tina Overton, 123. 


\section{Copyright Disclaimer}

Copyright for this article is retained by the author(s), with first publication rights granted to the journal.

This is an open-access article distributed under the terms and conditions of the Creative Commons Attribution license (http://creativecommons.org/licenses/by/3.0/). 